\title{
The Ross operation: Are we doing enough?
}

\author{
Harold M. Burkhart, MD, ${ }^{a}$ Jess L. Thompson, MD, ${ }^{a}$ and Arshid Mir, $\mathrm{MD}^{\mathrm{b}}$
}

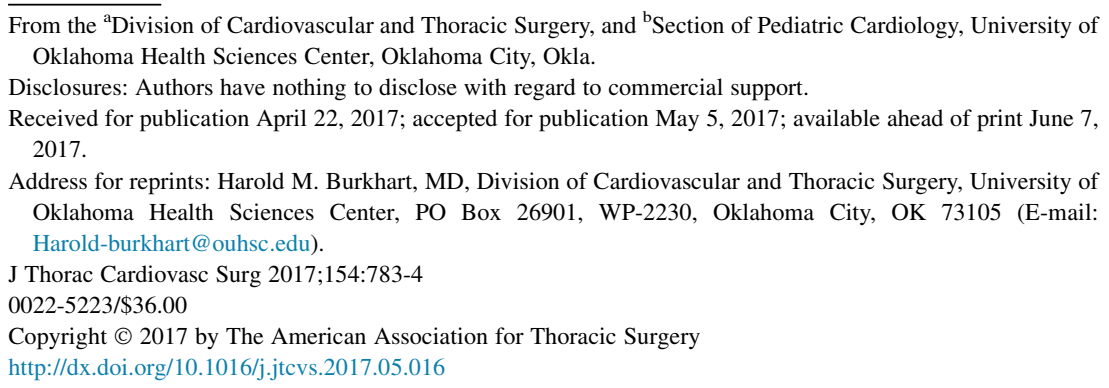

From the ${ }^{\mathrm{a}}$ Division of Cardiovascular and Thoracic Surgery, and ${ }^{\mathrm{b}}$ Section of Pediatric Cardiology, University of Oklahoma Health Sciences Center, Oklahoma City, Okla.

Disclosures: Authors have nothing to disclose with regard to commercial support.

Received for publication April 22, 2017; accepted for publication May 5, 2017; available ahead of print June 7 , 2017.

Address for reprints: Harold M. Burkhart, MD, Division of Cardiovascular and Thoracic Surgery, University of Oklahoma Health Sciences Center, PO Box 26901, WP-2230, Oklahoma City, OK 73105 (E-mail: Harold-burkhart@ouhsc.edu).

J Thorac Cardiovasc Surg 2017;154:783-4 $0022-5223 / \$ 36.00$

Copyright (C) 2017 by The American Association for Thoracic Surgery http://dx.doi.org/10.1016/j.jtcvs.2017.05.016

One of the biggest challenges when replacing the aortic valve in children and young adults is deciding on the best replacement prosthesis. In a perfect world, the valve would be readily available, allow for growth, not require anticoagulation, be simple to implant, and last a lifetime. Unfortunately, none of the current valve options are perfect. Aortic valve homografts have limited durability, can be difficult to obtain, and are associated with the need for a redo, calcified aortic root replacement in many patients. Bioprosthetic aortic valves do not last long in the young and are often coupled with higher gradients in children. Mechanical valves can present problems with increased gradients in children and obviously have issues related to anticoagulation. In addition, and important to the pediatric patients, none of the aforementioned valves allow for growth.

In this issue of the Journal, Ouzounian and colleagues ${ }^{1}$ succinctly present data substantiating their belief that the Ross operation provides superior freedom from death and valve-related complications, as well as maintains the desired quality of life when performed in young and middle-aged patients. The opinion article is important and should be required reading for a number of reasons. First, the authors give an excellent summary of the strengths and limitations of the currently available aortic valve substitutes for young and middle-aged patients. Second, they provide recent references supporting the use of the Ross procedure over prosthetic valve replacement. ${ }^{2,3}$ Points of these references include excellent hemodynamics, survival similar to that of matched general population, improved freedom from cardiac and valve-related mortality, and reduction in the incidence of stroke and major bleeding. Finally, they point out that to achieve these excellent results, the surgeon must perform the Ross procedure with regularity, be facile with aortic root procedures, and be part of an experienced team versed in the intraoperative and postoperative management of these patients.

Given the current superb results reported by the authors and others, ${ }^{4-6}$ one has to question whether we are performing enough Ross operations. There are likely 2

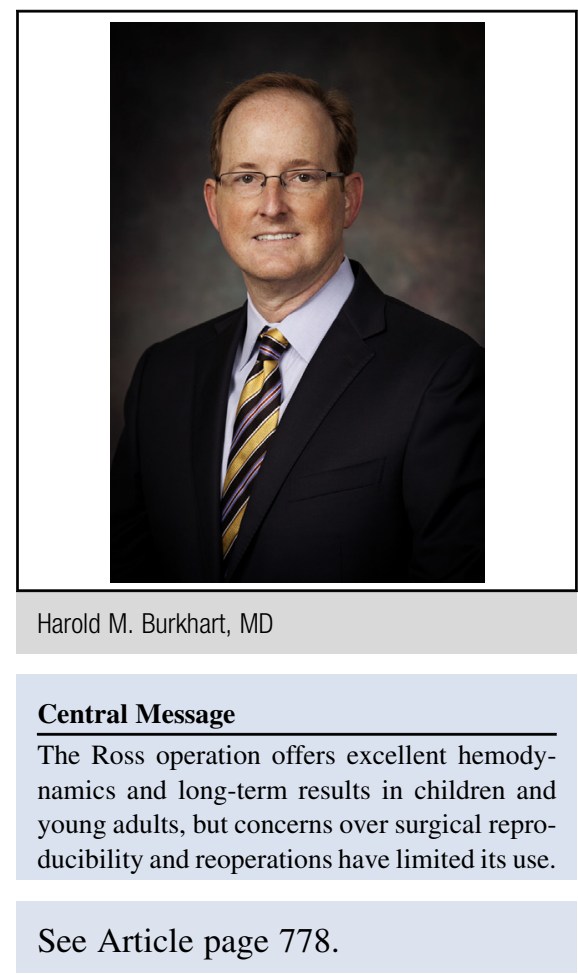

primary reasons that the use of the Ross procedure has not grown in the adult population. ${ }^{7}$ First, compared with a standard mechanical aortic valve replacement, the Ross operation is technically more challenging and faced with risks not associated with a stented valve replacement. Issues with pulmonary valve harvest and coronary artery reimplantation may not be appealing to every adult cardiac surgical practice. The authors do stress on more than 1 occasion that the surgeon should have regular experience with aortic root surgery before offering the Ross procedure.

Second, there are concerns that the reoperation requirement after the Ross procedure is high and the reoperations are complex. ${ }^{8}$ However, there are several modifications that have resulted in increasing the freedom from reoperation. Brown and colleagues ${ }^{4}$ have made changes in how the autograft is implanted, including annular and sinotubular junction fixation and ascending aorta reduction or replacement when appropriate. In addition, rigid blood pressure control for 3 to 6 months postoperatively have resulted in only a $6 \%$ aortic root reintervention rate since 2000. Avoiding excess native pulmonary artery tissue above the commissures in the autograft and keeping the neoaortic valve in a subannular position are recommended. In an effort to decrease aortic root dilation, others have reported 
modifications, including suspending the autograft in a prosthetic graft, ${ }^{9}$ reinforcing the root with a bioresorbable material, ${ }^{10}$ or supporting the root with autologous tissue (Paul Stelzer, personal communication, October 2016). Oversizing the pulmonary homograft and resecting excess muscle have increased the time to right ventricular outflow tract intervention. The advent of catheter-based pulmonary valve replacement has also decreased the need for surgical intervention.

The Ross procedure is associated with excellent hemodynamics and increased freedom from valve-related complications. It is reasonable to consider in carefully selected adults (eg, anticipated life expectancy of 15 years, active lifestyle, few comorbidities). The operation can be challenging and should be performed only by experienced aortic root surgeons with knowledgeable teams.

\section{References}

1. Ouzounian M, Mazine A, David TE. The Ross operation is the best operation to treat aortic stenosis in young and middle-aged adults. J Thorac Cardiovasc Surg. 2017; $154: 778-82$.
2. Sharabiani MT, Dorobantu DM, Mahani AS, Turner M, Tometzki AJ, Angelini GD, et al. Aortic valve replacement and the Ross operation in children and young adults. J Am Coll Cardiol. 2016;67:2858-70.

3. Mazine A, David TE, Rao V, Hickey EJ, Christie S, Manlhiot C, et al. Long-term outcomes of the Ross procedure versus mechanical aortic valve replacement: propensity-matched cohort study. Circulation. 2016;134:576-85.

4. Brown JW, Parth PM, Lin JI, Habib AS, Rodefeld MD, Turrentine MW. Ross versus non-Ross aortic valve replacement in children: a 22-year single institution comparison of outcomes. Ann Thorac Surg. 2016;101:1804-10.

5. Elkins RC, Thompson DM, Lane MM, Elkins CC, Peyton MD. Ross operation: 16-year experience. J Thorac Cardiovasc Surg. 2008;136:623-30.

6. Stelzer P, Itagaki S, Varghese R, Chikwe J. Operative mortality and morbidity after the Ross procedure: a 26-year learning curve. J Heart Valve Dis. 2013;22: 767-75.

7. Yacoub MH, El-Hamamsy I, Sievers HH, Carabello BA, Bonow RO, Stelzer P, et al. Under-use of the Ross operation — a lost opportunity. Lancet. 2014;384: 559-60.

8. Stulak JM, Burkhart HM, Sundt TM III, Connolly HM, Suri RM, Schaff HV, et al. Spectrum and outcome of reoperations after the Ross procedure. Circulation. 2010;122:1153-8.

9. Slater M, Shen I, Welke K, Komanapalli C, Ungerleider R. Modification to the Ross procedure to prevent autograft dilation. Semin Thorac Cardiovasc Surg Pediatr Card Surg Annu. 2005:181-4.

10. Nappi F, Spadaccio C, Fouret P, Hammoudi N, Chachques JC, Chello M, et al. An experimental model of the Ross operation: development of a resorbable reinforcements for pulmonary autografts. J Thorac Cardiovasc Surg. 2015;149: 1134-42. 